\title{
Author Correction: Estimate the hidden deployment cost of predictive models to improve patient care
}

Keith E. Morse D, Steven C. Bagley and Nigam H. Shah iD

Correction to: Nature Medicine https://doi.org/10.1038/s41591-019-0651-8, published online 13 January 2020.

In the version of this article initially published, the second author's surname ('Bagely') was incorrect. The correct name is 'Bagley'. The error has been corrected in the HTML version of the article.

Published online: 14 April 2020

https://doi.org/10.1038/s41591-020-0862-z

(c) Springer Nature America, Inc. 2020

\section{Author Correction: Safety and feasibility of anti-CD19 CAR T cells with fully human binding domains in patients with B-cell lymphoma}

Jennifer N. Brudno, Norris Lam, Danielle Vanasse, Yueh-wei Shen, Jeremy J. Rose, John Rossi, Allen Xue, Adrian Bot, Nathalie Scholler (D), Lekha Mikkilineni, Mark Roschewski, Robert Dean, Raul Cachau (D), Philippe Youkharibache, Rashmika Patel, Brenna Hansen, David F. Stroncek, Steven A. Rosenberg, Ronald E. Gress and James N. Kochenderfer (D)

Correction to: Nature Medicine https://doi.org/10.1038/s41591-019-0737-3, published online 20 January 2020.

In the version of this article initially published, a value in the final sentence of the legend to Extended Data Fig. 8 (spots/40,000 total input PBMC) was incorrect (twice). The correct value is 'spots/400,000 total input PBMC' (for both). The error has been corrected in the HTML and PDF versions of the article.

Published online: 14 April 2020

https://doi.org/10.1038/s41591-020-0864-X

(c) The Author(s), under exclusive licence to Springer Nature America, Inc. 2020 